\title{
12. ARCHAEOMONADS AS EOCENE AND OLIGOCENE GUIDE FOSSILS IN MARINE SEDIMENTS
}

\author{
Andrew M. Gombos, Jr., Antarctic Research Facility, Department of Geology, \\ Florida State University, Tallahassee, Florida
}

\section{INTRODUCTION}

The Archaeomonadaceae are a family of fossil marine chrysomonadins, presumably planktonic in life habitat, characterized by siliceous cysts of spherical or ovoid form with a minute round opening or pore on their top side (Stradner, 1971). Archaeomonads are known as fossils from the Late Cretaceous to Miocene, only recently having been reported from the Oligocene by Perch-Nielsen (1975).

Tynan (1971), in a report on the known geologic occurrences of archaeomonads, noted that "there are no reported occurrences of the archaeomonads in the Oligocene." He attributed this "absence" of Oligocene archaeomonads to a lack of study of sediments of that age. This appears to have been the case as PerchNielsen (1975) has recently reported the first occurrences of Oligocene archaeomonads from two DSDP Leg 29 sites: Site $278\left(56^{\circ} 33.42^{\prime} \mathrm{S}, 160^{\circ} 04.29^{\prime} \mathrm{E}\right)$ in the Emerald Basin and Site $280\left(48^{\circ} 57.44^{\prime} \mathrm{S}\right.$, $147^{\circ} 14.08^{\prime} \mathrm{E}$ ) south of the South Tasman Rise.

Three new archaeomonad species of the genus Archaeosphaeridium were described by Perch-Nielsen (1975) from the late Eocene and Oligocene at these sites. The three species, Archaeosphaeridium australensis, A. tasmaniae, and A. dumitricae, consist, basically, of smooth spheres to which spines of varying lengths and orientations are attached. One of the species, $A$. tasmaniae, is the first reported archeomonad with very long spines.

During the preparation of the diatom report for this volume, the occurrence of the three above-mentioned archaeomonad species was noted in late Eocene and Oligocene samples from Site $328\left(49^{\circ} 48.67^{\prime} \mathrm{S}\right.$, $36^{\circ} 39.53^{\prime} \mathrm{W}$ ) in the Malvinas Outer Basin in the South Atlantic Ocean (Figure 1). These, quite distinctive species, appear to have potential as guide fossils to Eocene and Oligocene age sediments; therefore, their distribution at Site 328 is presented here.

\section{METHODS}

Each slide was examined for archaeomonads by making a series of 10 traverses over the cover slip ( $18 \times$ $18 \mathrm{~mm})$ at $160 \times$ magnification. Each archaeomonad observed in this manner was noted. The same slides used in the diatom investigation (this volume) were used for this study.

\section{RESULTS}

The results of counting are presented in Table 1. The numbers in each column under taxa headings refer to actual counts of specimens made during 10 traverses.

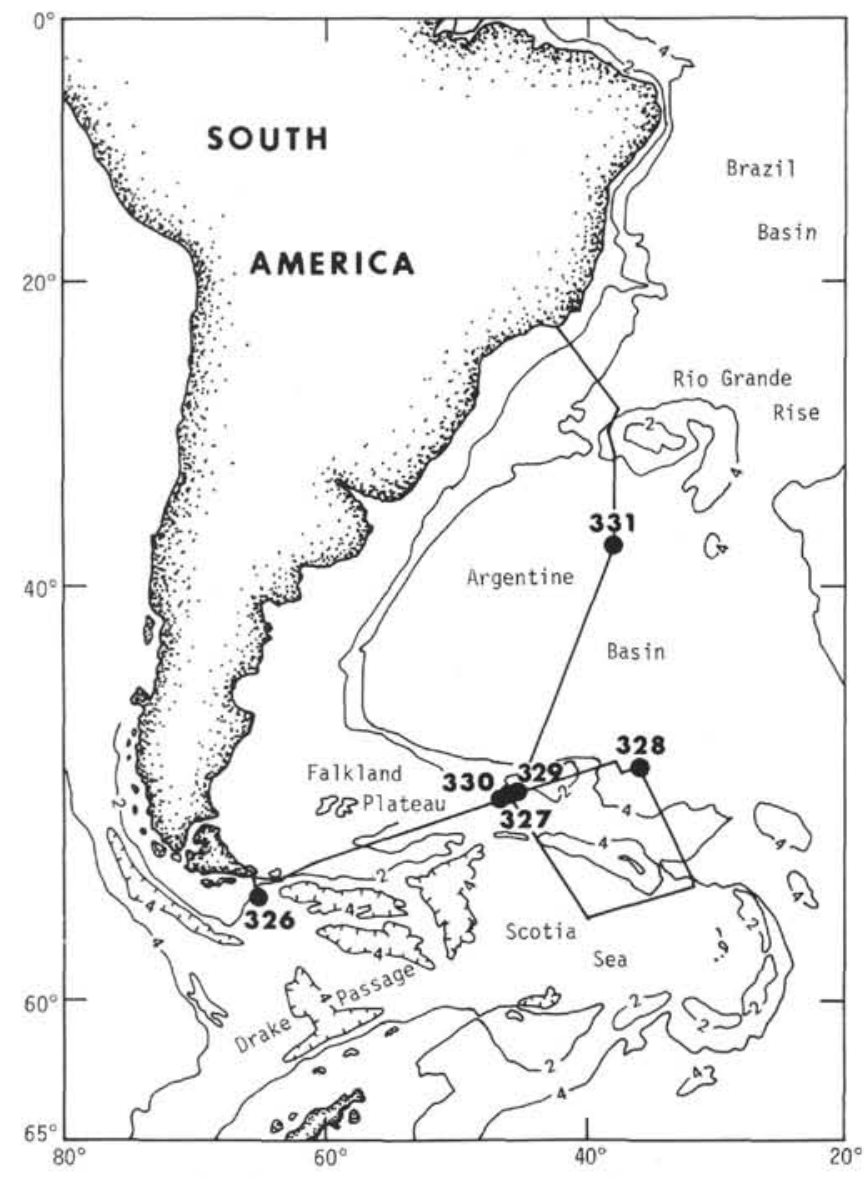

Figure 1. Location map of Leg 36 sites.

None of the species under investigation were observed in Samples 3-1, 5-7 cm through 3-6, 70-72 cm, although diatoms are present in these samples. Samples $5-1,9-11 \mathrm{~cm}$ and 5-3, 5-7 cm and Samples 5-4, 29-31 cm through $5-6,27-29 \mathrm{~cm}$ are barren of diatoms as well as archaeomonads.

The archaeomonads are never abundant in the samples studied. They are always subordinate in number to diatoms and other siliceous microfossils. Archaeosphaeridium australensis and A. tasmaniae were the most abundant of the three species, occurring in greatest numbers in the Oligocene (though not ranging completely through this interval) and in greatly reduced numbers in the late Eocene. Only two occurrences of $A$. dumitricae were noted in the present material. These rare occurrences were in the late Eocene. Perch-Nielsen (1975) also records $A$. dumitricae only in the late Eocene in Leg 29 material. 
TABLE 1

Distribution and Abundances of Archaeosphaeridium australensis, A. tasmaniae, and $A$. dumitricae in the Late Eocene and Oligocene in Hole 328B in the Malvinas Outer Basin, South Atlantic Ocean

\begin{tabular}{|c|c|c|c|c|c|}
\hline & Age & $\begin{array}{c}\text { Sample } \\
\text { (Interval in } \mathrm{cm} \text { ) }\end{array}$ & 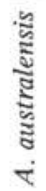 & 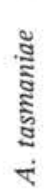 & 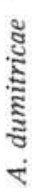 \\
\hline & $\begin{array}{c}\text { Early } \\
\text { Miocene }\end{array}$ & $\begin{array}{l}3-1,5-7 \\
3-1,145-147 \\
3-2.70-72\end{array}$ & $\begin{array}{l}- \\
-\end{array}$ & $\begin{array}{l}- \\
- \\
-\end{array}$ & - \\
\hline 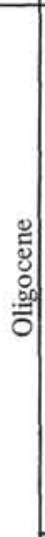 & Late & $\begin{array}{l}3-3,5-7 \\
3-3,143-145 \\
3-4,70-72 \\
3-5,5-7 \\
3-5,143-145 \\
3-6,70-72 \\
3-6,85-87 \\
3-6,126-128 \\
4-1,45-47 \\
4-1,144-146 \\
4-2,5-7 \\
4-2,131-133 \\
4-3,70-72 \\
4-3,145-147 \\
4-4,5-7 \\
4-4,147-149 \\
4-5,3-5 \\
\end{array}$ & $\begin{array}{l}- \\
- \\
- \\
- \\
- \\
- \\
3 \\
2 \\
4 \\
5 \\
1 \\
8 \\
1 \\
8 \\
5 \\
7 \\
27\end{array}$ & $\begin{array}{l}\overline{-} \\
- \\
- \\
- \\
- \\
- \\
\overline{4} \\
4 \\
\overline{16} \\
\overline{6} \\
3 \\
2 \\
9\end{array}$ & $\begin{array}{l}\text { - } \\
\overline{-} \\
\overline{-} \\
\overline{-} \\
\overline{-} \\
\overline{-} \\
\overline{-} \\
\overline{-} \\
- \\
\overline{-} \\
- \\
-\end{array}$ \\
\hline & Early & $4-5,145-147$ & 3 & 1 & $=$ \\
\hline 荧 & Late & $\begin{array}{l}5-1,9-11 \\
5-1,147-149 \\
5-2,70-72 \\
5-3,5-7 \\
5-3,65-67 \\
5-3,84-86 \\
5-4,29-31 \\
5-5,29-31 \\
5-6,27-29\end{array}$ & $\begin{array}{l}\overline{-} \\
2 \\
1 \\
- \\
- \\
- \\
- \\
- \\
-\end{array}$ & $\begin{array}{l}\overline{2} \\
1 \\
- \\
- \\
- \\
- \\
-\end{array}$ & $\begin{array}{l}\overline{-} \\
1 \\
1 \\
- \\
- \\
- \\
- \\
-\end{array}$ \\
\hline
\end{tabular}

Other species of archaeomonads (various species of the genus Archaeomonas) were rare or absent in most of the samples. Perch-Nielsen reported other species of archaeomonads to be rare or to occur only sporadically in the Oligocene of Leg 29 material (Perch-Nielsen, 1975).

\section{SUMMARY}

It appears that species of the archaeomonad genus Archaeosphaeridium have potential use as guide fossils to sediments of late Eocene and Oligocene age. The dis- tribution of three species of this genus in late Eocene and Oligocene sediment from Site 328 in the South Atlantic Ocean compares favorably with the distribution of the same species in late Eocene and Oligocene sediments recovered by DSDP Leg 29 south of Australia and New Zealand. A. dumitricae appears to be restricted to the late Eocene. A. tasmaniae and $A$. australensis range from late Eocene to late Oligocene but are most abundant in the Oligocene.

\section{SYSTEMATIC PALEONTOLOGY \\ Genus ARCHAEOSPHAERIDIUM Deflandre (1932) \\ Archaeosphaeridium australensis Perch-Nielsen (1975) \\ (Plate 1, Figures 1-8)}

Description; Perch-Nielsen (1975), p. 878, p. 2, fig. 1-10.

Remarks: This species is characterized by a short neck of over half the diameter of the cyst, and 1 to 3, long, downward pointing spines.

Occurrence: This species was observed in late Eocene to late Oligocene sediments from Site 328.

\section{Archaeosphaeridium dumitricae Perch-Nielsen (1975)} (Plate 1, Figure 9)

Description: Perch-Nielsen (1975), p. 878, pl. 2, fig. 11-17.

Remarks: This species is characterized by a number of short, broad-based, robust spines in all directions. These spines are often connected by thin siliceous walls.

Occurrence: This species was observed only in late Eocene samples from Site 328.

\section{Archaeosphaeridium tasmaniae Perch-Nielsen (1975)}

(Plate 1, Figure 10; Plate 2, Figures 1-5)

Description: Perch-Nielsen (1975), p. 878, pl. 2, fig. 18-23, pl. 3, fig. $1-10$, pl. 12 , fig. $1-3$.

Remarks: This species is characterized by 2 to 6 very long spines oriented in any direction.

Occurrence: This species was observed in late Eocene and Oligocene samples from Site 328 .

\section{REFERENCES}

Perch-Nielsen, K., 1975. Late Cretaceous to Pleistocene archaeomonads, ebridians, endoskeletal dinoflagellates, and other siliceous microfossils from the Subantarctic southwest Pacific, DSDP, Leg 29. In Kennett, J.P., Houtz, R.WE., et al., Initial Reports of the Deep Sea Drilling Project, Volume 29: Washington (U.S. Government Printing Office), p. 873-908.

Stradner, H., 1971. On the ultrastructure of Miocene Archaeomonadaceae (Phytoflagellates) from Limberg, Lower Austria. In Farinacci, A. (Ed.), Plankt. Conf. second Rome, 1970 Proc., Roma (Tecnoscienza), p. 11831199.

Tynan, E.J., 1971. Geologic occurrence of the archaeomonads. In Farinacci, A. (Ed.), Plankt. Conf. second Rome, 1970 Proc., Roma (Tecnoscienza), p. 1225-1230. 



\section{PLATE 1}

Figures 1-8 Archaeosphaeridium australensis Perch-Nielsen.

1. Sample 328B-4-5, 3-5 cm (640X).

2. Sample 328B-4-5, 3-5 cm $(660 \times)$.

3. Sample 328B-4-4, $147-149 \mathrm{~cm}(660 \times)$.

4. Sample 328B-4-1, 144-146 cm (640X).

5. Sample 328B-4-5, 3-5 cm (660×).

6. Sample 328B-4-4, $147-149 \mathrm{~cm}(680 \times)$.

7. Sample 328B-4-2, 131-133 cm (640X).

8. Sample $328-4-1,147-149 \mathrm{~cm}(660 \times)$.

Figure 9 Archaeosphaeridium dumitricae Perch-Nielsen. Sample 328B-5-1, 147-149 cm (640X).

Figure 10 Archaeosphaeridium tasmaniae Perch-Nielsen. Sample 328-4-1, 147-149 cm (800×). 
PLATE 1
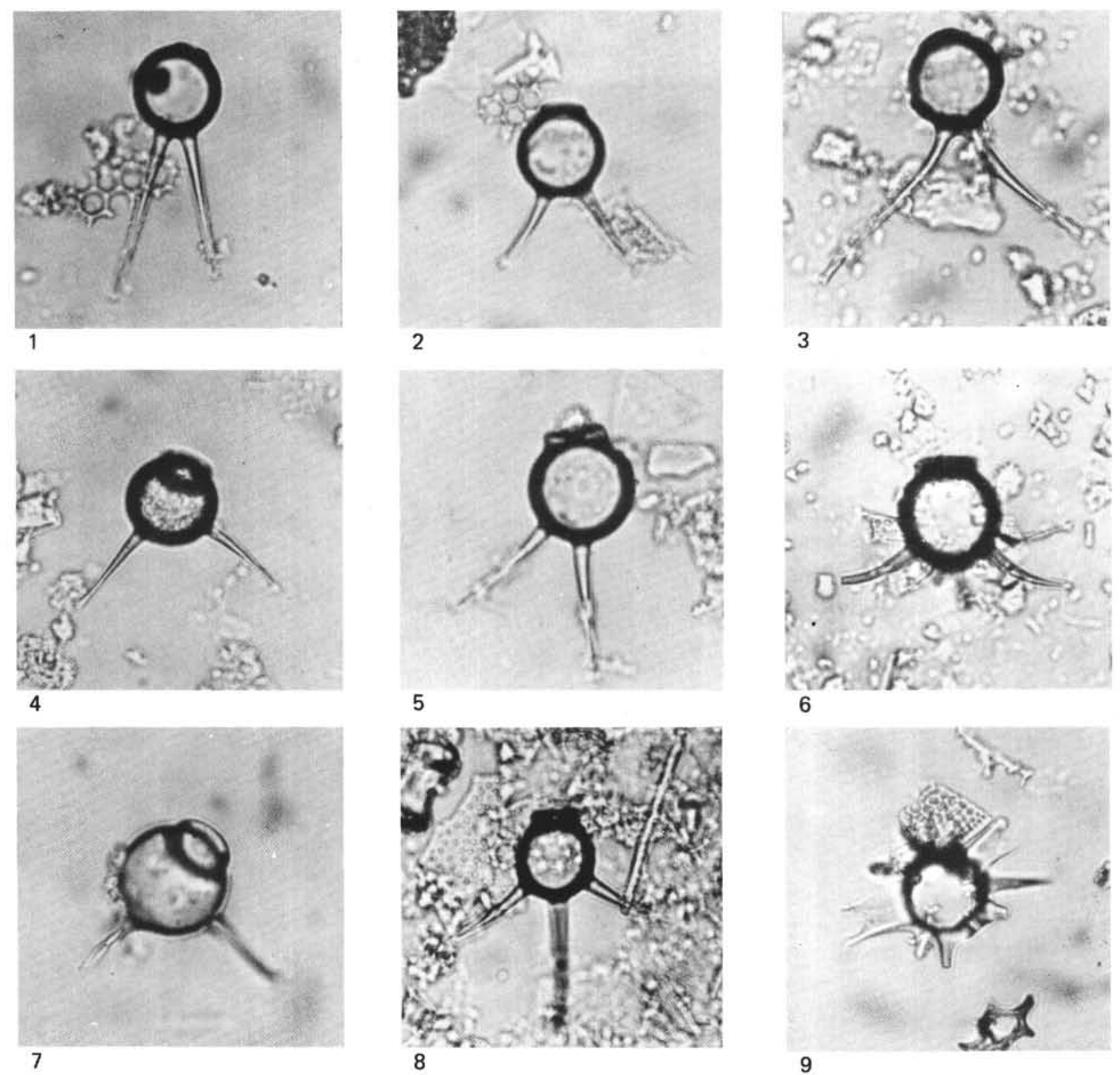

6
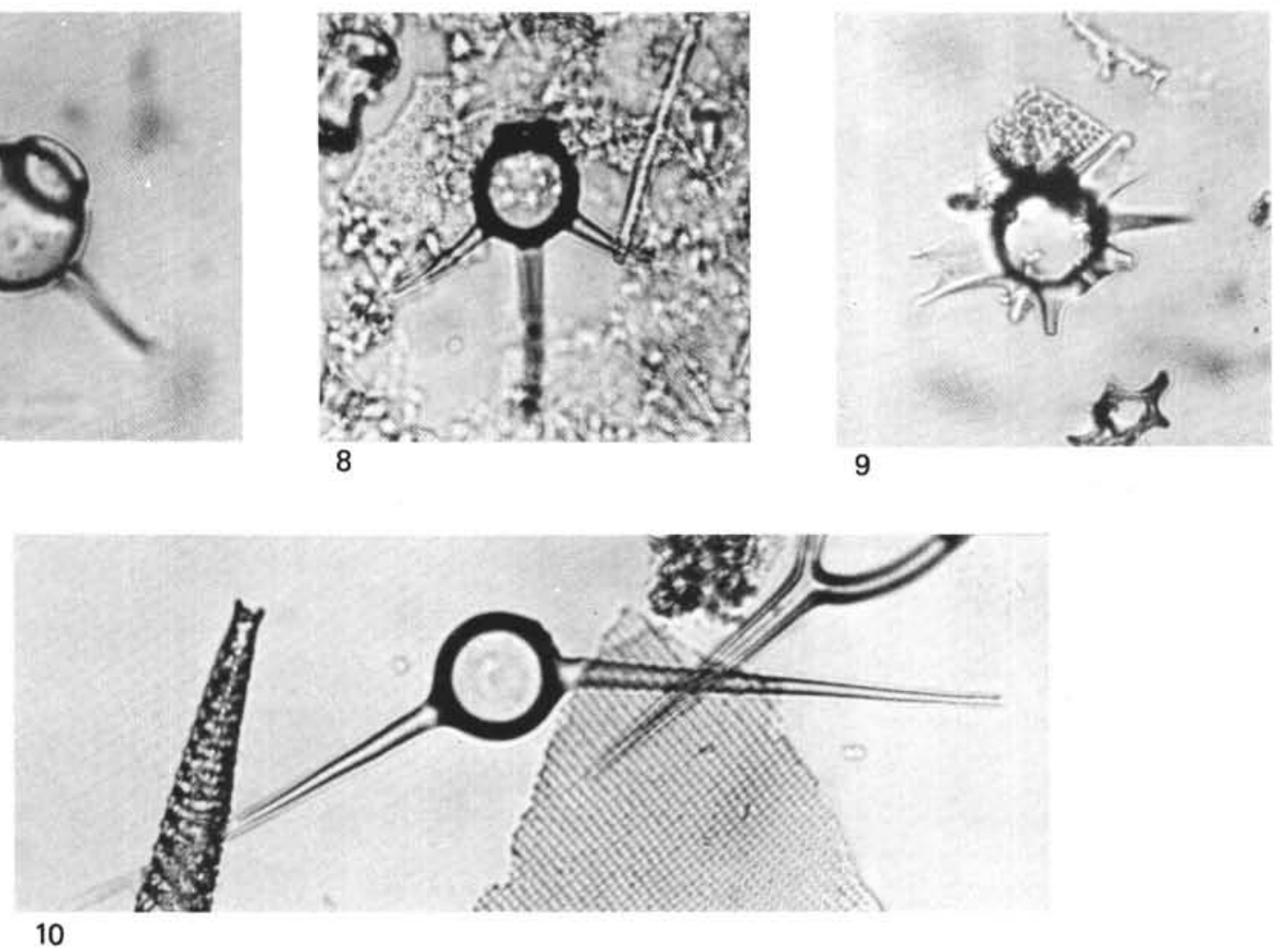


\section{PLATE 2}

Figures 1-5 Archaeospaeridium tasmaniae Perch-Nielsen.

1. Sample 328B-4-2, $131-133 \mathrm{~cm}(860 \times)$.

2. Sample 328B-4-3, $145-147 \mathrm{~cm}(640 \times)$.

3. Sample 328B-4-1, $144-146 \mathrm{~cm}(820 \times)$.

4. Sample 328B-4-3, $145-147 \mathrm{~cm}(680 \times)$.

5. Sample 328-4-1, 147-149 cm (680X). 


\section{PLATE 2}
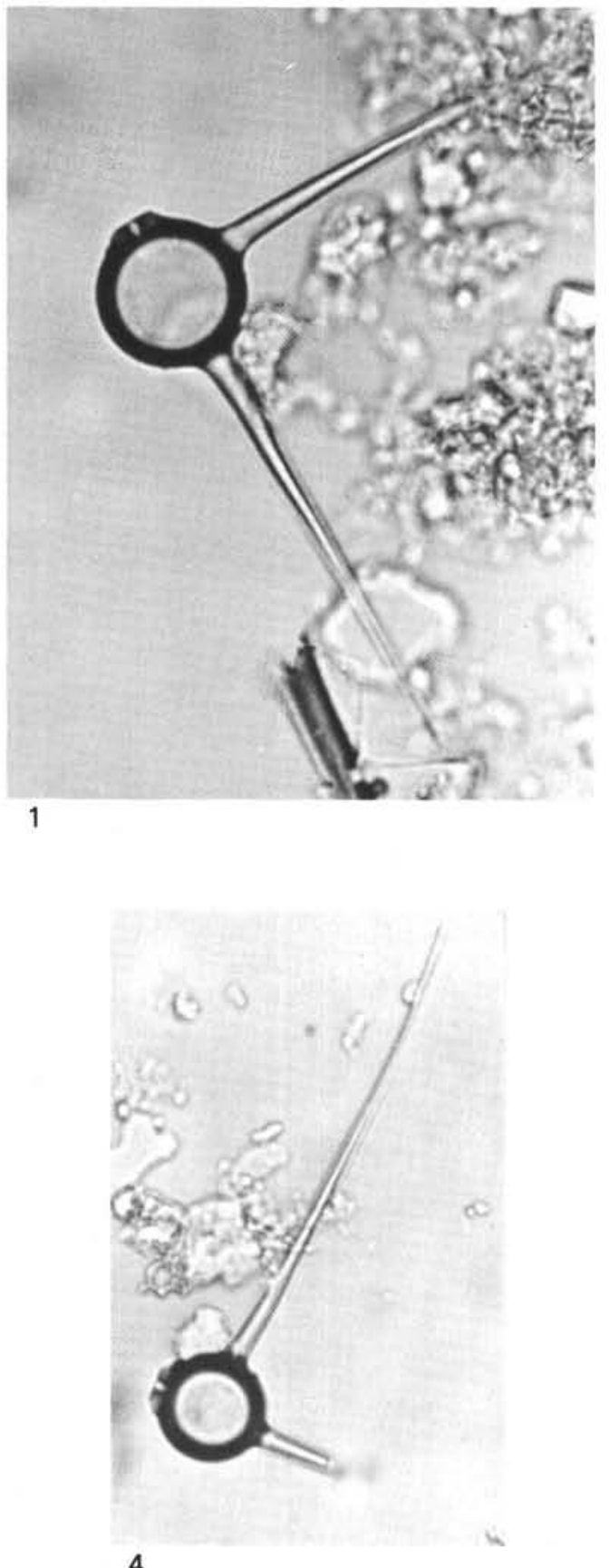
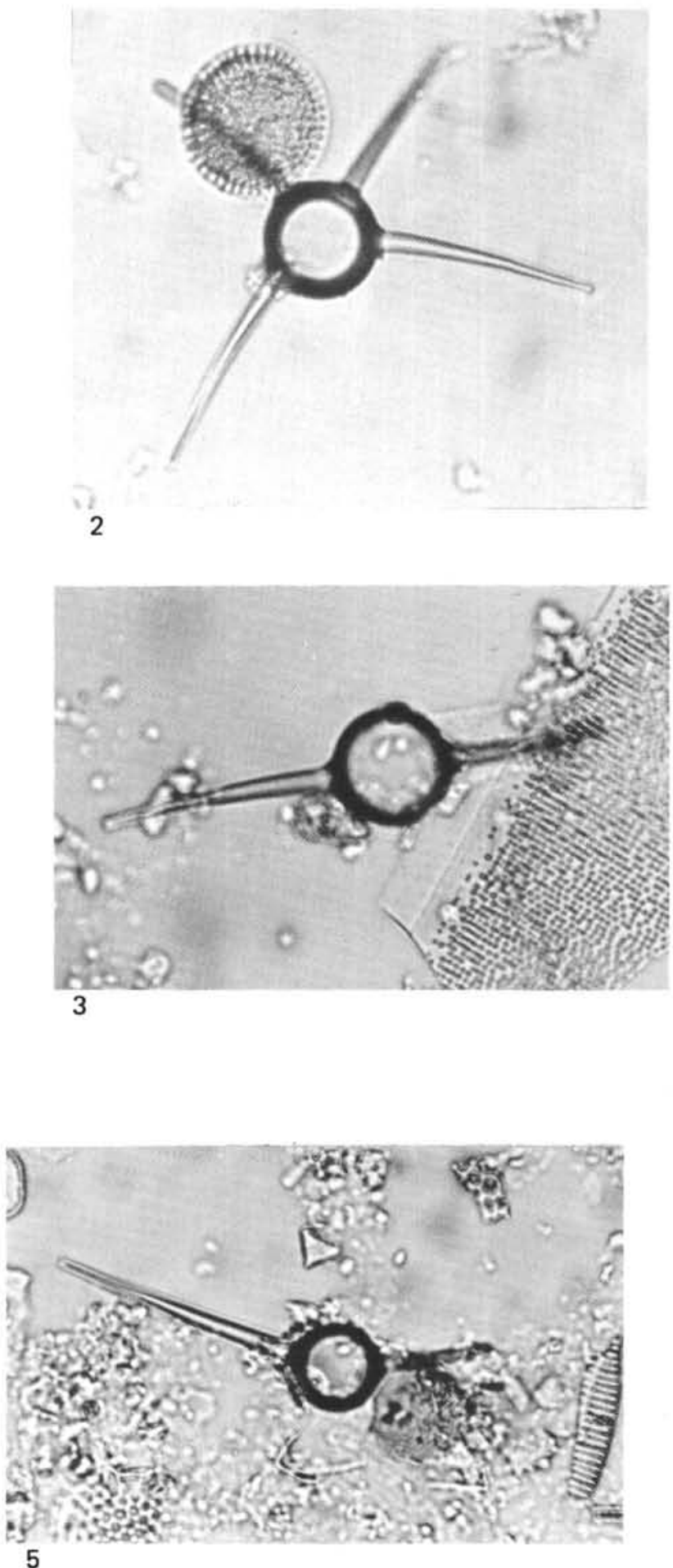